\title{
Appropriate Internal Appeal Mechanisms for Approval of Building Plans: Exploring the Gaps Left by the Constitutional Court
}

\section{P.E.R}

Pioneer in peer-reviewed, open access online law publications

Authors

Ngwako Raboshakga

Oliver Fuo

Affiliation

North-West University, South Africa

Email

Ngwako.Raboshakga@nwu.ac.za Oliver.Fuo@nwu.ac.za

Date Submission

7 February 2020

Date Revised

15 September 2020

Date Accepted

15 September 2020

Date published

16 September 2020

\section{Editor Prof H Chitimira}

How to cite this article

Raboshakga $\mathrm{N}$ and Fuo $\mathrm{O}$

"Appropriate Internal Appeal

Mechanisms for Approval of

Building Plans: Exploring the Gaps

Left by the Constitutional Court"

PER / PELJ 2020(23) - DOI

http://dx.doi.org/10.17159/1727-

3781/2020/v23i0a7938

Copyright

DOI

http://dx.doi.org/10.17159/1727-

3781/2020/v23i0a7938

\section{Abstract}

This article explores the gaps left by the Constitutional Court's jurisprudence in relation to what the appropriate internal appeal mechanism should be at the level of municipalities for the approval of building plans. This follows the unanimous judgment of the Constitutional Court in City of Johannesburg Metropolitan Municipality $v$ Chairman of the National Building Regulations Review Board 20185 SA 1 (CC) in which the Court found section 9 of the National Building Regulations and Building Standards Act 103 of 1977 (NBR Act), subjecting municipal building decisions to appeal by a "Review Board" appointed by the Minister of Trade and Industry, to be inconsistent with the original constitutional powers of municipalities over planning and building regulations. We argue that although the ground for holding section 9 of the NBR Act unconstitutional is already deeply entrenched in the Court's planning jurisprudence, the judgment has left a whopping gap on where prospective/future appeals can be lodged and the nature of such an appeal mechanism, where municipal officials disapprove building plans in terms of section 7 of the NBR Act. It is submitted that the invalidation of section 9 by the Court has completely left it up to each individual municipality to decide on whether and how an internal appeal for the approval of building plans is to be pursued. After exploring the options available in terms of other local government legislation, we argue that the most appropriate way to close the gap left by the Court is for Parliament to enact an amendment to the NBR Act providing for an internal appeal mechanism that allows for a measure of coherence and uniformity across municipalities, and yet respects the autonomy of local government.

\section{Keywords}

South African municipalities; building regulations; exclusive executive powers; building plans; review of municipal decisions. 


\section{Introduction}

In terms of section 156(1)(a) and Schedule 4B of the Constitution of the Republic of South Africa, 1996 (hereafter, the Constitution) municipalities have original legislative and executive powers over building regulations. These powers are closely linked to their planning powers that also appear in Schedule 4B of the Constitution. National and provincial governments have legislative and executive powers to ensure that municipalities effectively perform their original powers and functions by regulating their executive authority as defined in section 156(1) of the Constitution. ${ }^{1}$ The Constitutional Court recently held that the regulatory powers of national and provincial governments in this context are limited to creating norms and guidelines for the exercise of a municipal power or for the performance of a municipal function and do not allow national or provincial governments to usurp the original power or perform the original function of a municipality. ${ }^{2}$ This means setting broad norms and standards in which context municipalities can effectively exercise their original powers and functions. It is important to note that the original constitutional powers of municipalities over building regulations are regulated by national legislation which predates the Constitution - the National Building Regulations and Building Standards Act 103 of 1977 (NBR Act).

In this article we use the unanimous judgment of the Constitutional Court in City of Johannesburg Metropolitan Municipality $v$ Chairman of the National Building Regulations Review Board 20185 SA 1 (CC) (hereafter CoJ Metropolitan Municipality $v$ Chairman of the NBR Review Board) as a spring-board to discuss and propose an appropriate appeal mechanism for decisions on the approval of building plans made at local government level under the NBR Act. The Court found section 9 of the NBR Act, which provided an internal appeal mechanism for the approval of building plans created and staffed at a national government level, inconsistent with the

Ngwako Raboshakga. LLB LLM (with distinction) (WITS). Senior Lecturer, Faculty of Law, NWU, (Potchefstroom Campus), South Africa. E-mail: Ngwako.Raboshakga@nwu.ac.za. ORCID ID: https://orcid.org/0000-0002-82000623

** $\quad$ Oliver Fuo. LLB (Univ of Buea) LLM LLD (NWU). Associate Professor, Faculty of Law, NWU (Potchefstroom Campus), South Africa. Email: Oliver.Fuo@nwu.ac.za. ORCID ID: https://orcid.org/0000-0002-1442-8599. Corresponding author.

See ss 155(6)-(7) of the Constitution.

Minister of Local Government, Environmental Affairs and Development Planning, Western Cape $v$ The Habitat Council; Minister of Local Government, Environmental Affairs and Development Planning, Western Cape v City of Cape Town 20144 SA 437 (CC) (Minister of Local Government v The Habitat Council) para 22. See Fuo 2017 De Jure 328-331. 
original constitutional powers of municipalities over building regulations. ${ }^{3}$ We argue that although the ground for holding section 9 of the NBR Act unconstitutional is already deeply entrenched in the Court's planning jurisprudence,${ }^{4}$ the judgment has left a gap in the regulation of where prospective/future appeals can be lodged and the nature of such an appeal mechanism, where municipal officials disapprove building plans in terms of section 7 of the NBR Act. ${ }^{5}$ We begin in Parts 2 and 3 of this paper by giving a synopsis of the jurisprudence of the Constitutional Court on the original powers of municipalities regarding building regulations and municipal planning and how these powers were violated by national legislation, resulting in the invalidation of provisions of such national legislation. In Part 4 we discuss the character and work of the National Building Regulations Review Board that was prescribed in section 9 of the NBR Act, and is now discontinued after section 9 was declared unconstitutional. In Part 5 we discuss the general character of internal appeals in the South African context. In exploring what internal appeal mechanism would be appropriate for future decisions on building plans, in Part 6 we compare the erstwhile section 9 of the NBR Act with internal appeal mechanisms provided in section 62 of the Local Government: Municipal Systems Act 32 of 2000 (Systems Act) and the more recent appeal mechanism developed in the Spatial Planning and Land Use Management Act 16 of 2013 (SPLUMA). This, with a view to determining which existing features could usefully inform the creation of an internal appeal mechanism fitting for decisions on building

3 Section 9 of the National Building Regulations and Building Standards Act 103 of 1977 (the NBR Act) provided:

"Appeal against decision of local authority

(1) Any person who-

(a) feels aggrieved by the refusal of a local authority to grant approval referred to in section 7 in respect of the erection of a building;

(b) feels aggrieved by any notice of prohibition referred to in section 10; or

(c) disputes the interpretation or application by a local authority of any national building regulation or any other building regulation or by-law,

may, within the period, in the manner and upon payment of the fees prescribed by regulation, appeal to a review board.

(2) The review board referred to in subsection (1) shall consist of-

(a) a chairman designated by the Minister [of Trade and Industry]; and

(b) two persons appointed for the purpose of any particular appeal by the said chairman from persons whose names are on a list compiled in the manner prescribed by regulation."

4 See City of Johannesburg Metropolitan Municipality v Gauteng Development Tribunal 20106 SA 182 (CC) (CoJ Metropolitan Municipality v Gauteng Development Tribunal) para 57; Minister of Local Government, Environmental Affairs and Development Planning of the Western Cape $v$ Lagoonbay Lifestyle Estate (Pty) Ltd 20141 SA 521 (CC) para 46; Minister of Local Government v The Habitat Council paras 13-19.

$5 \quad$ This same question was raised rhetorically by Justice O'Regan in Walele $v$ City of Cape Town 20086 SA 129 (CC) paras 141-142. 
plans. In Part 7 we express an opinion on what the current position is on internal appeal mechanisms for the approval of building plans before we make recommendations on legislative interventions that could be made and what ought to inform such interventions. Here we argue that the invalidation of section 9 has completely left it up to each individual municipality to decide on whether and how internal appeals in respect of the approval of building plans shall be pursued. As will become evident from the discussion below, we argue that there could be drawbacks to this fragmented approach, which might lead to a lack of coherence and uniformity in the adjudication of appeals of decisions on building plans. Such incoherence and lack of uniformity has for characterised the debate on efficiency of internal administrative appeal mechanisms in South Africa for long time. We argue that the most appropriate way to close the gap left by the Constitutional Court in CoJ Metropolitan Municipality $v$ Chairman of the NBR Review Board is for Parliament to enact an amendment to the NBR Act providing for an internal appeal mechanism, thus allowing for a measure of coherence and uniformity across municipalities yet respecting the autonomy of local government. We make concluding remarks in Part 8.

\section{Background: CoJ Metropolitan Municipality v Chairman of the NBR Review Board}

\subsection{Facts of the case}

In terms of the NBR Act, the construction of buildings in a municipal area must be subject to prior approval of the building plans by the relevant municipality and any construction of a building without the necessary municipal approval constitutes a criminal offence which is punishable by a fine in terms of section $4(4) .{ }^{6}$ Subject to the relevant provisions of the Act, a municipality is empowered to approve or disapprove the building plans upon recommendation by its building control officer. ${ }^{7}$ The Act does not prescribe who within the municipality must make the final decision on building plans pursuant to the building control officer's recommendation. In terms of section 9 of the NBR Act, read with the National Building Regulations ${ }^{8}$ and the Review Board Regulations, ${ }^{9}$ applicants dissatisfied with the non-

$6 \quad$ See ss 4 and 7 of the NBR Act. The term "building" is defined very broadly in $\mathrm{s} 1$ of the Act to include permanent or temporary structures used for rendering any service - this will include cellular phone masts.

$7 \quad$ The powers of municipalities to appoint building control officers and their functions are outlined in ss $4-5$ of the Act.

GN R2378 in GG 12780 of 12 October 1990 (National Building Regulations).

GN 2074 in GG 9927 of 13 September 1985 (Review Board Regulations). 
approval of their building plans by a municipality were allowed to appeal to a Review Board, which was constituted by three persons, one of whom was a chairman appointed by the Minister of Trade and Industry. ${ }^{10}$ In terms of these arrangements, the Review Board exercised appellate jurisdiction over the application of municipal by-laws, policies and decisions on building regulations. ${ }^{11}$

In view of its constitutional powers over building regulations, the City of Johannesburg adopted the City of Johannesburg Cellular Mast Policy ${ }^{12}$ in order to govern applications for building plans relating to the erection of cellular phone mast (communication towers) in its area of jurisdiction. ${ }^{13}$ The Mast Policy provides that applications of this kind will be determined in terms of section 7 of the NBR Act. ${ }^{14}$ The Cellular Mast Policy outlines the process that should be followed for submitting plans for approval and accords owners of property adjacent to where the mast is to be erected a hearing before the decision to approve is taken. These land owners may submit their written representations to the City within 21 days of being requested to do so.

In June 2012 ATC South Africa Wireless Infrastructure (Pty) Ltd submitted to the City an application for the approval of plans to erect a cellular mast on its property. In line with its Policy, the City gave the relevant adjacent property owners an opportunity to make representations on the application. Although two of them objected to the erection of the mast, the City approved the plans and the mast was erected on ATC's property. Dissatisfied by the approval, in 2013the objectors lodged an appeal with the Review Board against the decision of the City. ${ }^{15}$ Before the Review Board, the City argued mainly that the Board should dismiss the application on the ground that it had no jurisdiction over the matter. The City's argument therefore did not address the merits of the appeal. After considering written submissions, the Review Board issued a ruling in 2015 rejecting the City's arguments. In its ruling, the Review Board ordered the City to submit its response to the factual arguments and merits of the appeal within 21 days, subsequent to which the appellants in the matter would be provided an opportunity to

10 City of Johannesburg Metropolitan Municipality $v$ Chairman of the National Building Regulations Review Board 20185 SA 1 (CC) (CoJ Metropolitan Municipality v Chairman of the NBR Review Board) paras 5-7. CoJ Metropolitan Municipality v Chairman of the NBR Review Board paras 6-7.

See City of Johannesburg Date Unknown http://www.joburgtourism.com/ files/useruploads/user_anon/files/apps_cellmast.pdf. CoJ Metropolitan Municipality $v$ Chairman of the NBR Review Board para 8. See ss 7(1), (3)-(7) of the NBR Act for details. CoJ Metropolitan Municipality $v$ Chairman of the NBR Review Board para 9. 
reply. ${ }^{16}$ Unhappy with the ruling, the City instituted proceedings in the High Court seeking an order declaring section 9 of the Act invalid and unconstitutional to the extent that it authorised the Review Board to usurp a municipal function and asked for the Board's ruling to be set aside. The City argued that section 9 of the Act empowered an organ of state in the national sphere of government to exercise powers which the Constitution reserved exclusively for municipalities. ${ }^{17}$

Based on a number of cases decided by the Constitutional Court, ${ }^{18}$ the High Court held that section 9 of the NBR Act was inconsistent with the Constitution because it impermissibly authorised the Review Board to exercise the planning functions of municipalities. ${ }^{19}$ The High Court declared section 9 of the Act invalid and set aside the decision of the Review Board. It declared the appeal that was pending before the Review Board void $a b$ initio. As required by the Constitution, the High Court's order declaring section 9 of the Act constitutionally invalid and of no force and effect had to be confirmed by the Constitutional Court. ${ }^{20}$

\subsection{Main decision and remedy}

In a unanimous judgment written by Justice Jafta, the Constitutional Court held that the High Court was correct in concluding that section 9 of the NBR Act was inconsistent with the Constitution and accordingly confirmed the declaration of invalidity. ${ }^{21}$ The Constitutional Court's decision was based on how the Constitution protects the autonomy of local government vis-à-vis the other spheres of government and how this gives effect to the principle of the separation of powers among three spheres of government. ${ }^{22}$ The Court indicated that, in terms of section 156(1) read with Schedule 4B of the Constitution, municipal planning and building regulations are exclusive executive competencies of municipalities. ${ }^{23}$ The Court indicated that when the City approved ATC's building plans to erect a cellular phone mast on its property, the City was exercising its constitutional powers pertaining to building regulations and municipal planning. ${ }^{24}$ The Court observed that

CoJ Metropolitan Municipality v Chairman of the NBR Review Board paras 10-11. CoJ Metropolitan Municipality v Chairman of the NBR Review Board para 13.

See CoJ Metropolitan Municipality v Gauteng Development Tribunal; Minister of Local Government v The Habitat Council; Tronox KZN Sands (Pty) Ltd v KwaZuluNatal Planning and Development Appeal Tribunal 20163 SA 160 (CC). CoJ Metropolitan Municipality $v$ Chairman of the NBR Review Board para 16. CoJ Metropolitan Municipality $v$ Chairman of the NBR Review Board paras 18-19. CoJ Metropolitan Municipality $v$ Chairman of the NBR Review Board para 38. CoJ Metropolitan Municipality v Chairman of the NBR Review Board paras 20-38. CoJ Metropolitan Municipality $v$ Chairman of the NBR Review Board paras 23-24. CoJ Metropolitan Municipality v Chairman of the NBR Review Board para 25. 
although national and provincial governments enjoy legislative authority over matters entrusted to the local sphere, the Constitution does not empower these spheres to exercise the executive authority of municipalities. The Court indicated that the role played by the national sphere in municipal affairs is restricted to regulating the exercise of power by municipalities and capacitating municipalities to manage their own affairs through regulating how this must be done. The regulatory power of national government does not mean that it may by itself take over and exercise the executive authority of a municipality. ${ }^{25}$ The Court asserted that there "is no constitutional provision that allows a member of Cabinet to intervene in the exercise of constitutional powers by municipalities. This intervention is at odds with the separation of powers created by the constitutional scheme mentioned earlier."26 The Court indicated that although there is a general exception in section 139 of the Constitution, the intervention in the case before it was not "concerned with an intervention of that kind. Instead, we are dealing with interference by the Minister and the Board who belong to the national sphere of government."27 The Court asserted that:

\begin{abstract}
The legislative power that the national and provincial spheres exercise over functional areas allocated to the local sphere does not include the power to arrogate to themselves executive powers vested in the local sphere by the Constitution. The exercise of the executive authority of municipalities is the sole preserve of municipalities... The fact that section 9 of the Act empowers the Minister and the Board to intervene on appeal does not change the position to a constitutionally compliant one. And certainly, what is authorised by the impugned provision goes beyond the power of regulating the exercise by municipalities of their executive authority referred to in section 156(1). The Board may reverse the decision of a municipality. This override is not a decision of a municipality but of the Board. ${ }^{28}$
\end{abstract}

Based on the above reasoning and its jurisprudence in previous cases, the Court concluded that the High Court was right in concluding that section 9 of the Act was inconsistent with the Constitution and upheld the declaration of invalidity. ${ }^{29}$ One can argue that this approach was inevitable given the Court's earlier ruling in Minister of Local Government $v$ The Habitat Council, where it found that a "full-blown" appellate jurisdiction by a provincial authority on a municipal planning matter (a power bestowed on local government under Schedule 4(B), read with section 156(1), of the CoJ Metropolitan Municipality $v$ Chairman of the NBR Review Board paras 34 and 35.

26 CoJ Metropolitan Municipality $v$ Chairman of the NBR Review Board para 26.

27 CoJ Metropolitan Municipality $v$ Chairman of the NBR Review Board para 27. CoJ Metropolitan Municipality $v$ Chairman of the NBR Review Board para 38. 
Constitution) was constitutionally impermissible and that the executive authority of such matters belonged to municipalities "alone". ${ }^{30}$

In terms of remedy, the Court accepted as sensible the proposal by the City of Johannesburg that the order of invalidity should operate prospectively and that it should not affect pending appeals - the processing of pending appeals should not be disrupted but finalised without delay by a Review Board constituted in terms of section 9 of the Act. ${ }^{31}$ However, the Court rejected the City's proposal that future appeals should be processed in terms of section 62 of the Local Government: Municipal Systems Act 32 of 2000. ${ }^{32}$ The Court held that:

30 Minister of Local Government $v$ The Habitat Council para 16. It had also been observed by Fuo that: "A cogent principle distilled from the jurisprudence of the Court emanating from the cases in the area of planning law is that a decision taken by a municipality pursuant to powers protected in its exclusive area of constitutional competence cannot be subjected to appeal to a functionary or entity operating within the national or provincial sphere of government. This also means that legislation, executive policies or regulations cannot subject such decisions to appeal at the national or provincial level. Doing so would violate the constitutional vision of autonomous spheres of government which dictates that national and provincial spheres of government not be entitled to usurp the exclusive constitutional powers and functions of municipalities, barring exceptional circumstances." Fuo 2017 De Jure 345. CoJ Metropolitan Municipality $v$ Chairman of the NBR Review Board paras 40 and 43.

Section 62 of the Local Government: Municipal Systems Act 32 of 2000 (the Systems Act) reads as follows:

"(1) A person whose rights are affected by a decision taken by a political structure, political office bearer, councillor or staff member of a municipality in terms of a power or duty delegated or sub-delegated by a delegating authority to the political structure, political office bearer, councillor or staff member, may appeal against that decision by giving written notice of the appeal and reasons to the municipal manager within 21 days of the date of the notification of the decision.

(2) The municipal manager must promptly submit the appeal to the appropriate appeal authority mentioned in subsection (4).

(3) The appeal authority must consider the appeal, and confirm, vary or revoke the decision, but no such variation or revocation of a decision may not detract from any rights that may have accrued as a result of the decision.

(4) When the appeal is against a decision taken by -

(a) a staff member other than the municipal manager, the municipal manager is the appeal authority;

(b) the municipal manager, the executive committee or executive mayor is the appeal authority, or, if the municipality does not have an executive committee or an executive mayor, the council of the municipality is the appeal authority; or

(c) a political structure or political office bearer, or a councillor -

(i) the municipal council is the appeal authority where the council comprises more than 15 councillors or

(ii) or a committee of councillors who were not in the decision and appointed by the municipal council for this purpose is the appeal authority where the council comprises of more than 14 councillors. 


\begin{abstract}
This section is simply not suitable. Decisions to which section 9 of the Act applied are those which were taken by a municipality. Under section 62(4) of the Systems Act, a municipal council is the highest appeal authority. Therefore, if section 62 were to apply, a municipality would sit on appeal against its own decisions. This would be an untenable situation. ${ }^{33}$ Consequently, it is just and equitable to have pending appeals processed in terms of section 9 of the Act. But this process must exclude the appeal lodged in the present matter. The High Court declared that appeal to have been void and its order was not challenged before this Court. ${ }^{34}$
\end{abstract}

In brief, the Court confirmed that section 9 of the NBR Act was invalid to the extent that it empowers the National Building Regulations Review Board to exercise appellate powers over decisions of a municipality on building plans.

\title{
3 Background: Johannesburg Metropolitan Municipality v Gauteng Development Tribunal and the enactment of SPLUMA
}

Prior to 1995 the Town-Planning and Townships Ordinance 15 of 1986 empowered "authorised" municipalities in what was then the Transvaal province to make decisions on the rezoning of land and township development. The City of Johannesburg was such an authorised municipality. After 1995 the Gauteng Provincial Government set up the Gauteng Development Tribunal in terms of chapters $\mathrm{V}$ and $\mathrm{VI}$ of the Development Facilitation Act 67 of 1995 (DFA). The latter Act empowered provincial governments to set up tribunals which would consider and decide on applications for rezoning and township development, effectively taking away the jurisdiction "authorised" municipalities in Gauteng had under the Town-Planning and Townships Ordinance to make final decisions on such applications.

Pursuant to disagreements between the City of Johannesburg and the Tribunal on the manner in which the Tribunal approached the approval of applications for rezoning and township development, the City of Johannesburg applied to court for an order declaring unconstitutional chapters $\mathrm{V}$ and $\mathrm{VI}$ of the DFA, arguing that the Act violated the constitutionally-enshrined autonomy of local government to approve applications on rezoning and township development. The South Gauteng High Court dismissed the application but granted the City leave to appeal to

(5) An appeal authority must commence with an appeal within six weeks and decide the appeal within a reasonable period.

(6) The provisions of this section do not detract from any appropriate appeal procedure provided for in any other applicable law." 
the Supreme Court of Appeal. ${ }^{35}$ The Supreme Court of Appeal found in favour of the City of Johannesburg, holding that chapters V and VI of the DFA were unconstitutional and invalid. ${ }^{36}$

The Constitutional Court confirmed the declaration of unconstitutionality. It held that in terms of section 156(1) read with Schedule 4(B) of the Constitution only municipalities were empowered to make decisions on the approval of rezoning and township development applications. The Court reasoned that in terms of the constitutional scheme the only circumstances where provincial governments could intervene in the affairs of local government were: (a) the temporary takeover of municipal powers in terms of section 139 of the Constitution in exceptional circumstances; (b) provincial governments monitoring and supporting municipalities in terms of sections 155(6)(a) of the Constitution; and (c) national and provincial governments regulating the exercise by municipalities of their executive authority in order to ensure effective performance by municipalities of their functions in terms of section 155(7) of the Constitution - which power is limited to setting broad norms and guidelines for application by municipalities. ${ }^{37}$ The Court suspended the order of invalidity for 24 months to allow Parliament to rectify the defects in the Act or to pass new legislation. ${ }^{38}$

For the purposes of this article, the most significant development of the Johannesburg Metropolitan Municipality v Gauteng Development Tribunal case was the development and enactment of the legislation to replace chapters V and VI of the DFA, which had been declared unconstitutional. Instead of Parliament's just remedying the defects, the DFA was overhauled and ultimately repealed and replaced with SPLUMA. In the development of SPLUMA everything was on the cards, including what the appeal mechanism for rezoning and township development decisions within municipalities should be.

This background is given in order to determine how the approach in SPLUMA can inform what the appropriate appeal mechanism should be for the approval of building plans. We discuss the nature of the appeal mechanism developed in SPLUMA in Part 5 of this article. Suffice it to say,

\footnotetext{
35 City of Johannesburg Metropolitan Municipality $v$ Gauteng Development Tribunal 20084 SA 572 (W). City of Johannesburg Metropolitan Municipality $v$ Gauteng Development Tribunal 20102 SA 554 (SCA).

37 CoJ Metropolitan Municipality v Gauteng Development Tribunal paras 43 and 46. Also see Minister of Local Government v The Habitat Council para 22. CoJ Metropolitan Municipality v Gauteng Development Tribunal paras 79 and 95.
} 
for now, that SPLUMA locates the power to make decisions on rezoning and township development with a Municipal Planning Tribunal staffed with municipal officials and external experts. The authority to hear internal appeals is located with the executive authority of the municipality concerned, although this power can also be delegated elsewhere. At the centre of who should make approvals and hear internal appeals in the development of SPLUMA were considerations of the autonomy of local government.

Before providing an analysis of the impact of the declaration of section 9 of the NBR Act as unconstitutional, we find it useful to set out the nature of the now defunct National Building Regulations Review Board, how it operated, and the importance of internal appeals in the South African context.

\section{The nature of the National Building Regulations Review Board and its operations}

Section 20(1) of the NBR Act empowers the Minister of Trade and Industry to make regulations pertaining to the work of the Review Board. The Review Board Regulations ${ }^{39}$ were promulgated in 1985. The Regulations provide the Director-General of the Department of Trade and Industry with discretionary authority to appoint and unappoint members of the Review Board, guided by the need to ensure that various branches of the construction industry are represented on the board. Various organisations involved in the construction industry may nominate candidates to the Director-General. ${ }^{40}$ The chairman of the Review Board is designated by the Minister in terms of section 9(2)(a) of the NBR Act. The list of members of the Review Board must be kept transparent. ${ }^{41}$

The Regulations provide an elaborate procedure for appeals to the Review Board. If a matter is complex the Board is empowered to set it down for a hearing where witnesses can be summoned and compelled to give evidence under oath. ${ }^{42}$ Legal representation and inspections in loco are also permitted. ${ }^{43}$ Failure by a witness to comply with a summons is deemed to be a criminal offence. ${ }^{44}$ The Regulations also contain measures for avoiding conflicts of interest by members of the Review Board. ${ }^{45}$ Appeal decisions

\footnotetext{
39 GN 2074 in GG 9927 of 13 September 1985 (Review Board Regulations).

40 Regulations 2-6 and 8 of the Review Board Regulations.

41 Regulation 7 of the Review Board Regulations.

42 Regulations 11 and 12(4) of the Review Board Regulations.

43 Regulation 12 of the Review Board Regulations.

44 Regulation 11(2)(a) of the Review Board Regulations.

45 Regulation 11(3) of the Review Board Regulations.
} 
are taken by a majority vote of the three-member panel, which may dismiss the appeal, confirm the refusal, grant conditional approval or uphold the appeal in whole or in part. ${ }^{46}$ The panel may also order compensation. ${ }^{47} \mathrm{~A}$ record of proceedings must be kept in safe custody and be transparent and accessible. $^{48}$

The work of the Review Board is administered by the National Regulator for Compulsory Specifications (NRCS), which inter alia has a mandate to assist and advise the Minister of Trade and Industry in giving effect to the objectives of the NBR Act and the National Building Regulations. ${ }^{49}$ The Director-General of the Department of Trade and Industry is empowered to delegate to the staff of the NRCS his or her powers in terms of the Review Board Regulations. ${ }^{50}$ Indeed, the Minister relied on the NRCS to coordinate the work of the Review Board. ${ }^{51}$

We reviewed five decisions of the Review Board available on the NRCS website. ${ }^{52}$ These decisions reveal a number of features about the Review Board which are worth noting: (a) the chairperson and members of the Board in each instance were experts in construction, law and/or dispute resolution;53 (b) the judgments were written in a similar manner to court/arbitration judgments, referring both to legislative provisions and case law; (c) the analysis and application that had to be made involved the interpretation of legal provisions; 54 (d) evidence presented (including that of expert witnesses) had to be analysed and applied to the relevant

46 Regulation 13 of the Review Board Regulations.

47 Regulation 13 of the Review Board Regulations.

48 Regulation 16 of the Review Board Regulations.

49 See the NBR Act generally, the National Regulator for Compulsory Specifications Act 5 of 2008 and NRCS 2019 https://www.nrcs.org.za/content_main.asp?menu $\mathrm{ID}=12$.

50 Regulation 17 of the Review Board Regulations.

51 See NRCS 2019 https://www.nrcs.org.za/content_main.asp?menulD=12.

52 See NRCS $2019 \mathrm{https}: / / w w w . n r c s . o r g . z a / c o n t e n t . a s p ? s u b I D=4151 \# 1$. The following decisions were reviewed: Byron Janse Van Rensburg $v$ Ekurhuleni Metropolitan Municipality (23 March 2015); LKJ Fire Engineering Consultant v Nelson Mandela Bay Municipality (22 February 2017); Mediclinic Southern Africa (Pty) Ltd v Ekurhuleni Municipality (24 August 2015); Misty Sea Trading 339 (Pty) Ltd v City of Cape Town Municipality (14 November 2016); and Rowmoor Investments 156 (Pty) Ltd $v$ City of Cape Town Municipality (8 November 2016).

53 In the decisions reviewed the chairman was either Michael Bester or Ntando Ndonga. Michael Bester's profile indicates that he is an architect with extensive experience in dispute resolution, commercial mediation and arbitration. Ntando Ndonga is an expert and executive working in the legal, risk and governance sectors. In this regard, it is telling that s 9(1)(c) of the NBR Act provided that anyone who "disputes the interpretation or application by a local authority of any national building regulation or any other building regulation or by-law" had the right to appeal to the review board. 
regulations; (e) adjudication of the complaints needed technical expertise in the construction and engineering environments; ${ }^{55}$ and ( $f$ ) administrative law principles such as rationality, reasonableness, failure to apply the mind, authority and lawfulness had to be applied.

If anything, the role that has been played by the Review Board exposes the importance of experts making appeal decisions on matters pertaining to the NBR Act. We have not found any indication that the system of a review board made up of experts was unsuitable for decisions pertaining to the regulation of building, with the exception that in the present instance it violated the autonomy of local government, as found in CoJ Metropolitan Municipality $v$ Chairman of the NBR Review Board. Indeed, the violation of the autonomy of local government was the only criticism leveled against the system of a review board by the Constitutional Court. It would thus be fitting to consider whether the features of the Review Board established under section 9 of the NBR Act could be retained in any replacement internal appeal mechanism for decisions made under the NBR Act whilst curing the defect of violating the autonomy of local government.

\section{General character and importance of internal appeals in the South African context}

An internal appeal in the context of decisions made under the NBR Act is one contemplated in section 7(2)(a) of the Promotion of Administrative Justice Act 3 of 2000 (PAJA) which provides that: "no court or tribunal shall review an administrative action in terms of this Act unless any internal remedy provided for in any other law has first been exhausted [unless a court or tribunal deems an exemption to be in the interest of justice]". An administrative decision ${ }^{56}$ is valid until set aside either by the administrative body or by a court or tribunal on review. ${ }^{57}$ An internal appeal allows for the reconsideration of a decision of someone within an administrative body by someone belonging to or acting at the behest of that administrative body or

55 For example, in Byron Janse Van Rensburg v Ekurhuleni Metropolitan Municipality the Board remarked that "whether the building complies with [the] constraints [of the applicable town planning scheme] or not is a matter of empirical fact and not one that lies within the discretion of [municipal] officials."

56 Decisions on building plans fall within the purview of the definition of administrative action as defined in s 1 of the Promotion of Administrative Justice Act 3 of 2000 (PAJA).

57 See Georgiou v Nelson Mandela Bay Metropolitan Municipality 20164 All SA 524 (ECP); Oudekraal Estates (Pty) Ltd v City of Cape Town 20046 SA 222 (SCA) para 26; and MEC for Health, Eastern Cape v Kirland Investments (Pty) Ltd 20143 SA 481 (CC) paras 100-101. 
belonging to or at the behest of a body hierarchically higher than the administrative body that made the initial decision - in terms of any applicable legislation and the internal mechanisms of the administrative body concerned. ${ }^{58}$ Where no law exists permitting an internal appeal, it is deemed that there is no internal appeal mechanism applicable to decisions of the administrative body concerned. Accordingly, in South Africa there is no right to an internal remedy nor is there an obligation on an administrative body to apply an internal remedy where there is no specific law giving internal remedial power to that administrative body. ${ }^{59}$ On internal appeal, both the merits of the initial decision and the manner in which it was made can be reconsidered.

Counted amongst the advantages of internal appeal mechanisms are that they provide an accessible, cheaper, quicker and "democratically less threatening" platform. They also allow for the reconsideration of decisions that are technical, practical, of a policy nature and often specialised to be made by experts and people who work on such matters more regularly. ${ }^{60}$ Such administrators and experts also tend to have easier access to the relevant facts and information. ${ }^{61}$

Quinot et al caution that these advantages "depend largely on how the particular mechanism is set up in the legislation and (as with all regulatory mechanisms) how it is implemented."62 Hoexter cautions that although advantages of speed, efficiency and expertise exist in older and more established administrative systems, in some areas of the administration appeal processes have broken down "completely". ${ }^{63}$ It is for this reason that the consideration of a replacement of the internal appeal mechanism for decisions made under the NBR Act must be focussed on finding or

58 As Hoexter points out, an administrative appeal "enables the reconsideration of an administrative decision by a higher authority" and the "person or body to whom the appeal is made will step into the shoes of the original decision-maker, as it were, and decide the matter anew." Hoexter Administrative Law 65. Quinot et al Administrative Justice 100.

60 See Quinot et al Administrative Justice 102; Hoexter Administrative Law 66; Hoexter 2000 SALJ 497; Koyabe v Minister for Home Affairs 20104 SA 327 (CC) para 37. The Court in para 35 said: "Internal remedies are designed to provide immediate and cost-effective relief, giving the executive the opportunity to utilise its own mechanisms, rectifying irregularities first, before aggrieved parties resort to litigation. Although courts play a vital role in providing litigants with access to justice, the importance of more readily available and cost-effective internal remedies cannot be gainsaid."

$61 \quad$ Koyabe v Minister for Home Affairs 20104 SA 327 (CC) para 37.

62 Quinot et al Administrative Justice 102.

63 Hoexter Administrative Law 66. 
developing an internal appeal mechanism which achieves the advantages of internal administrative appeals.

Scholars of administrative law have identified that a major shortcoming in internal administrative appeal mechanisms in South Africa is the lack of uniformity and coherence. ${ }^{64}$ Referring to an earlier quote by Baxter, Govender observes that South Africa had "a disparate collection of appeal bodies with vastly differing modes of operation, and consequently different levels of effectiveness." 65 The incoherence of internal administrative appeal mechanisms in South Africa was recognised as early as in 1992 when the South African Law (Reform) Commission investigated courts' powers to review administrative acts. ${ }^{66}$ To date, however, the incoherence and lack of uniformity persist. Both Hoexter and Quinot et al point to the creation of appeal tribunal[s] with multiple jurisdictions over appeals from a variety of organs of state - akin to the Australian Administrative Appeals Tribunal as a possible solution to the problem of the "fragmented South African internal remedies landscape". 67

In this article we do not argue that there needs to be a single internal appeal mechanism for all decisions of administrative bodies, but for the principle that there needs to be a respectable measure of uniformity and coherence in the manner in which comparable internal appeal mechanisms work and, in particular, that there are demonstrable benefits in reducing the fragmentation of internal appeal mechanisms in building plan decisions in the local government sphere. Interestingly, under section 9 of the NBR Act the now defunct Review Board was a type of an appeal tribunal which had jurisdiction over decisions made in all municipalities in the country in terms of the NBR Act. However, for the reason that municipalities were not involved in the appointment of members of the Review Board, the appeal mechanism in section 9 of the Act was declared unconstitutional. It follows that an appeal tribunal of the Australian Appeal Tribunal type with jurisdiction over building plan decisions in all municipalities, even if it could be established in South Africa, would still run the risk of being found to violate local government autonomy and thus be susceptible to being found constitutionally invalid. Accordingly, whatever solution is found to the need to replace the appeal mechanism under section 9 of the NBR Act, issues of

64 See Quinot et al Administrative Justice 101-102; Hoexter Administrative Law 70-72; Hoexter 2000 SALJ 484.

65 Govender "Administrative Appeals Tribunals" 83. Also quoted by Hoexter Administrative Law 70.

$66 \quad$ SALC Project 2450.

67 Quinot et al Administrative Justice 101; Hoexter Administrative Law 71. 
incoherence and lack of uniformity would still have to be resolved whilst allowing each municipality the autonomy to have its own internal appeal structure.

\section{Comparison among the internal appeal mechanisms in section 9 of the NBR Act, section 62 of the Systems Act and section 51 of SPLUMA}

The erstwhile section 9 of the NBR Act, section 51 of SPLUMA and section 62 of the Systems Act provide internal appeal mechanisms which are worth comparing if we are to learn anything from developments that have taken place since the dawn of democracy in respect of internal appeals in the context of decisions of municipalities. Like the demise of the appeal mechanism under the NBR Act, the making of an internal appeal mechanism in SPLUMA was necessitated by the need to protect the autonomy of municipalities from undue interference by the national and/or provincial spheres of government. Thus the consideration of SPLUMA is inescapable in thinking about the type of appeal mechanism that would be suitable for appeals on municipal decisions concerning building plans. The need to consider section 62 of the Systems Act is equally inescapable as it was designed as a type of catch-all internal appeal mechanism for all decision-making in municipalities where no other law provided for an areaspecific internal appeal mechanism. ${ }^{68}$ We compare the internal appeal provisions in these three statutes for the purposes of this article in order to identify all of the factors that need to be considered in deciding on an appropriate appeal mechanism in relation to building plans, following the declaration of section 9 of the NBR Act as unconstitutional. We compare these provisions in terms of the following aspects: appeal against whom; appeal by whom and for whose benefit; who is the appeal authority; and overlaps.

\subsection{Appeal against whom?}

The NBR Act provided for "appeal against decision of local authority"; the Systems Act against "a decision taken by a political structure, political office bearer, councillor or staff member of a municipality"; and SPLUMA against "a decision taken by a Municipal Planning Tribunal". ${ }^{69}$ Therefore, the first

\footnotetext{
68 It should be noted that s 62(6) of the Systems Act has the effect that the latter will not apply where there exists legislation that provides for an internal appeal process for particular decisions by or within municipalities.

69 Sections 9 of the NBR Act (the heading), 62(1) of the Systems Act and 51(1) of the Spatial Planning and Land Use Management Act 16 of 2013 (SPLUMA).
} 
point of difference is that the NBR Act provided the power to approve building plans to the "local authority" without specifying who within the local authority must take the decision to approve building plans. Hence section 9 of the Act provided for an appeal against whomever the local authority has elected to make final decisions on building plans. The building control officer merely makes recommendations to the local authority. ${ }^{70}$

SPLUMA allocates the power to make decisions on applications for land use to a specialised Municipal Planning Tribunal (MPT). An MPT is composed of "officials in the full-time service of the municipality" as well as "persons appointed by the municipal council who are not municipal officials and who have knowledge and experience of spatial planning, land use management and land development or the law related thereto."71 Municipal councillors may not be appointed as members of an MPT. ${ }^{72}$ Thus, under SPLUMA, an internal appeal will be against the decision made by the MPT.

Section 62 of the Systems Act, on the other hand, is a general provision for appeals against decisions of anyone in the municipality, as long as the person was authorised by law to make such decision.

\subsection{Appeal by whom and for whose benefit?}

Section 9(2) of the NBR Act provided that anyone who was aggrieved by a decision of the local authority or who disputed the manner in which the local authority had interpreted a provision of the Act, a national building regulation or by-law, might appeal a decision of the local authority. The Supreme Court of Appeal has interpreted this provision to mean that it is available only to "persons who have applied unsuccessfully for approval for the erection of a building or have been prohibited from either commencing or continuing with building operations. ${ }^{73}$ In other words, third parties who had not objected to the decision of the local authority could not appeal to the Review Board. The Court went on to say:

How can a person appeal against a decision taken in proceedings in which he or she was not a party? The essence of an appeal is a rehearing (whether

\footnotetext{
70 Section 7 of the NBR Act provides that a local authority must consider the recommendation of the building control officer and then decide on whether to grant the approval or refuse to grant the approval of the building plans.

71 Section 36(1) of SPLUMA.

72 Section 36(2) of SPLUMA.

73 JDJ Properties CC v Umngeni Local Municipality 20132 SA 395 (SCA) para 42.
} 
wide or narrow) by a court or tribunal of second instance. Implicit in this is that the rehearing is at the instance of an unsuccessful participant in a process. ${ }^{74}$

Accordingly, the NBR Act provided what could be termed a narrow appeal not available to third parties who are affected by the decision of the municipality but who had not previously made an unsuccessful application to the municipality or lodged an objection with the municipality.

Section 62 of the Systems Act has also been interpreted similarly; it is available only to a person who had applied unsuccessfully to the municipality. It provides that "a person whose rights are affected by a decision" may appeal against such a decision. The Supreme Court Appeal has said that:

\begin{abstract}
It seems plain that the purpose of $\mathrm{s} 62$ as a whole is to give to the dissatisfied applicant for permission - and to no one else - an opportunity for the matter to be reheard by a higher authority within the municipality. It is only the aggrieved applicant, who has failed to secure the permission sought in his or her application, who is afforded a right of appeal under s $62 \ldots .$. Section 62 thus grants no viable appeal at all to a person not party to the [application to the municipality] ... [N]eighbours ... who are not party to an application or an objection to the grant of permission to act by a municipality - are not afforded an appeal under $\mathrm{s} 62 .{ }^{75}$
\end{abstract}

Section 62(3) also contains a proviso that a section 62 appeal is available only where rights have not accrued as a result of the decision. Thus, where a municipality has made an unconditional approval, a section 62 appeal is completely unavailable to any objector to a decision of a municipality. For this reason courts have held that section 62(3) has the effect that the section 62 appeal mechanism does not satisfy the section 7(2) of PAJA requirement that "an internal remedy provided for in any other law [must be] exhausted."76 In most instances once a municipality approves a building plan the right vests immediately in favour of the applicant, which in terms of section 62(3) of the Systems Act would take away the possibility of an appeal by any other party that claims to be affected.

On the contrary, SPLUMA provides that an appeal may be made by "a person whose rights are affected by the decision" and goes on to state that this includes (i) the person who unsuccessfully applied to the MPT; (ii) the municipality itself; and (iii) a person "who may reasonably be expected to be affected by the outcome of the land development application

74 JDJ Properties CC v Umngeni Local Municipality 20132 SA 395 (SCA) para 43. Footnote omitted.

75 Municipality of the City of Cape Town v Reader 20091 SA 555 (SCA) paras 31-35.

76 Municipality of the City of Cape Town v Reader 20091 SA 555 (SCA) paras 31-35. 
proceedings." 77 The latter includes interested third parties who were not party to the application that was considered and decided upon by the MPT. For the purposes of this article, we will call this a wide appeal. It should be noted that section 51(5) provides restrictions on third parties making appeals by stating that such a third party must have "a pecuniary or proprietary interest". Effectively the person must have a financial interest in the matter or must have a right over the property — such as ownership of the property.

\subsection{Who is the appeal authority?}

As explained above in the discussion of the CoJ Metropolitan Municipality $v$ Chairman of the NBR Review Board judgment, the appeal authority under section 9 of the NBR Act was a Review Board made up of a chairperson (appointed by the Minister of Trade and Industry) and two other members appointed by the chairperson. What is clear is that a municipality had no control or influence in appointing any of the members of the Review Board. This was held by the Constitutional Court to be unconstitutional for violating the autonomy of the local sphere of government.

Under section 62 of the Systems Act, the make-up of the appeal authority depends on the identity of the initial decision-maker. Where the initial decision-maker was a staff member, the municipal manager is the appeal authority. Where the initial decision-maker was the municipal manager, the executive committee or executive mayor (or, if the municipality does not have an executive committee or executive mayor, the municipal council) is the appeal authority. Where the initial decision-maker was "a political structure or political office bearer, or a councillor", the appeal authority is the municipal council or a committee of members of the municipal council. ${ }^{78}$ It follows that where the decision was made by the entire municipal council there cannot be an appeal authority as the municipal council is the highest decision-making body in a municipality. It is in this context that the Constitutional Court in CoJ Metropolitan Municipality v Chairman of the NBR Review Board held that section 62 of the Systems Act was not suitable as an appeal mechanism for decisions on building plans made by "a local authority" (as the power of the local authority effectively vests in the municipal council). The Court said that "if section 62 were to apply, a

Section 51(4) of SPLUMA.

Section 62(4) of the Systems Act. 
municipality would sit on appeal against its own decision [and that] this would be an untenable situation."79

In the case of SPLUMA the appeal authority is "the executive authority of the municipality." The person or body on whom the executive authority of a municipality is conferred depends on the type of the municipality. ${ }^{80}$ In a typical metropolitan municipality, this includes the mayor and the members of the mayoral committee (MMCs). What is important is that SPLUMA expressly provides that the municipal council may grant the power to decide appeals to a body or institution outside of the municipality in the place of the executive authority. ${ }^{81}$ In our view, such a body could be one that municipalities are required to be established in terms of national or provincial legislation, as long as they retain the powers to appoint relevant panel members. National or provincial legislation can only set minimum norms and standards on how municipalities should set up such appeal bodies. ${ }^{82}$ There does not seem to be a restriction on the executive authority's delegating this power to officials in the employ of the municipality or even to contracted experts. ${ }^{83}$ Heeding this possibility, some municipalities have set up appeal authorities made up of a panel constituted of a combination of officials, external experts and even councillors. For example, section 98 of the City of Ekurhuleni Metropolitan Municipality's Spatial Planning and Land Use Management By-Law permits the Municipal Council to set up an appeal authority consisting of at least 11 members made up of three officials employed by the Municipality, three persons not employed by the Municipality or any organ of state, two officials employed

CoJ Metropolitan Municipality v Chairman of the NBR Review Board para 41. Section 51(2) of SPLUMA.

Section 51(6) of SPLUMA. See further ss 8 to 10 of the Local Government: Municipal Structures Act 117 of 1998.

Indeed, reg 20(b) of the Regulations in terms of SPLUMA (GN R239 in GG 38594 of 23 March 2015 (SPLUMA Regulations)) contemplates that a municipality is entitled to authorise a body outside of the municipality to assume the obligations of an appeal authority.

Section 56 of SPLUMA dealing with delegation powers provides that:

"Any power, except the power to make regulations and the power to determine land use and land development applications as contemplated in section 35, conferred in this Act upon a Minister, a Premier or a municipality, may, in general or in cases of a particular nature, be delegated by the person or body entrusted with that power to a political office holder or an official in the employ or service of the relevant sphere of government: Provided that any such delegation must be in writing and must specify full particulars and the limitations of such a delegation."

The exception above does not apply to s 51 of SPLUMA. Reg 20(d) of the SPLUMA Regulations reads that the executive authority may delegate its authority to hear appeals to "an official or a panel of officials as contemplated in section 56 of the Act". 
by any organ of state in the national or provincial sphere of government, and six councillors of the Municipality.

\subsection{Overlaps in internal appeals provided for in more than one law}

Section 62 of the Systems Act anticipates that the legislature may create specific internal appeal procedures for specific areas, and thus states that "[t]he provisions of this section do not detract from any appropriate appeal procedure provided for in any other applicable law." ${ }^{84}$ The effect is that where legislation of greater specificity than the Systems Act provides for an internal appeal process, that process must be used to the exclusion of section 62 of the Systems Act. Indeed, in the case of decisions on municipal planning under SPLUMA, internal appeals may be dealt with only in terms of that Act. ${ }^{85}$ It follows as well that the internal appeal process that existed in section 9 of the NBR Act [prior to the finding of unconstitutionality] applied to the exclusion of section 62 of the Systems Act. Consequently, should the legislature enact a new internal appeal process under the NBR Act in the place of section 9, that internal appeal mechanism will apply to the exclusion of section 62 of the Systems Act.

\section{Discussion and way forward}

What is left to canvas is an analysis of what the current position is and what the options for the future of the regime are. What we find obvious is that the NBR Act, which preceded the Constitution by almost two decades, is certainly outdated and is not clearly aligned with the newly established constitutional powers and functions of local government. The fact that the approval of rezoning and township development applications was overhauled in the development of SPLUMA is an indication that the approval of building plans ought to be overhauled as well, especially since building regulation is considered an aspect of broader planning law. It will certainly not be surprising if the entire NBR Act is overhauled in the near future.

\subsection{Where are we now?}

The Constitutional Court in CoJ Metropolitan Municipality v Chairman of the NBR Review Board ordered that "section 9 of the [NBR Act] is invalid, to the extent that it empowers the [Review Board] to exercise appellate powers

84 Section 62(6) of the Systems Act.

85 In fact $\mathrm{S} 51$ of SPLUMA provides that "[n]o appeal in respect of a decision taken in terms of or pursuant to [SPLUMA] may be lodged in terms of section 62 of the Municipal Systems Act." Thus SPLUMA expressly excludes the application of s 62 of the Systems Act. 
over decisions of a municipality." It also ordered that the declaration of invalidity will operate prospectively from the date of the order. The Review Board was ordered to finalise without delay all appeals lodged with it before the date of the order. The order of the Court clearly indicated that, but for pre-existing appeals, the mandate of the Review Board was to cease immediately. However, the Court did not order Parliament to repair the defects in the NBR Act as was the case in Johannesburg Metropolitan Municipality $v$ Gauteng Development Tribunal, and did not decide on what is the appropriate internal appeal mechanism in respect of decisions under the NBR Act. The only guidance provided was that an appellate body in such decisions cannot be one established by and operated by the national or provincial spheres of government where local government has neither a say nor a choice. The Court also correctly averred that the appeal process provided for in section 62 of the Systems Act was not suited to internal appeals for decisions made under the NBR Act. ${ }^{86}$

The Court's not ordering Parliament to fix the defects in section 9 of the NBR Act is indicative that it was of the view that national legislation regulating internal appeals for decisions made under the NBR Act was not a necessity. This view is correct. As indicated above, in South Africa "there is no right to an internal remedy nor is there an obligation on an administrative body to apply an internal remedy where there is no specific law giving internal remedial power to that administrative body" - only that where such law exists the relevant internal appeal mechanism must be exhausted. ${ }^{87}$ The Court clearly left it to Parliament to decide whether or not such legislation is desirable. Further, "the law" referred to in PAJA need not be national legislation; it includes municipal by-laws. The result of this is that, as it stands, in respect of those municipalities which have passed bylaws regulating internal appeals for decisions under the NBR Act, such internal appeal mechanisms must be exhausted in terms of section 7(2)(a) of PAJA before review is sought in a court of law. The converse is that in respect of those municipalities where there are no by-laws regulating internal appeals for decisions made under the NBR Act, it will be deemed that there are no internal appeal mechanisms in those municipalities. The only recourse available to an unsuccessful applicant would be to approach the courts directly for judicial review of the municipality's decision. In the light of the advantages of internal appeals discussed above, this is of course 
not ideal, as courts would have to adjudicate very technical matters without the benefit of ventilation by experts at an internal appeal level.

The reality explained above is indicative of an environment of incoherence and lack of uniformity in respect of appeals against building plan decisions in municipalities. Not only will some municipalities not have an internal appeal mechanism in place, but municipalities may adopt mechanisms which differ from place to place drastically. Although this eventuality may be compliant with the constitutional scheme in respect of the autonomy of local government, a question arises as to what the impact of such a position is on good and effective governance. We have already demonstrated that the general regime of internal administrative appeal in South Africa suffers from challenges of incoherence and lack of uniformity. Without a general law governing internal appeals, it is dependent on context-specific legislation to achieve coherence and uniformity. Accordingly, the piecemeal environment we find ourselves in at this time appears to have worsened what is already an environment of incoherence and lack of uniformity. It is arguable that allowing municipalities to develop their own approaches to internal appeals on building plan decisions could promote democratic experimentation which may result in diverse and unique solutions being organically developed at local level. However, there is a balance to be achieved between such noble democratic experimentation and the national sphere's discharging its constitutional obligation to guide South Africa's 257 municipalities on the topic of building plan decision-making in order to ensure good governance, equity, responsiveness, accountability, rule of law and the visionary unity of the legal system. We address matter in some detail below.

\subsection{An appropriate internal appeal mechanism for decisions under the NBR Act}

In finding an appropriate solution it is trite to consider how the broader reading of the Constitution informs the debate. Section 195(1) of the Constitution sets out values and principles governing public administration in all spheres of government, amongst them: "[s]ervices must be provided impartially, fairly and equitably..."; "[p]eople's needs must be responded to"; and "[p]ublic administration must be accountable". ${ }^{88}$ These values are consistent with the constitutional values contained in section 1 of the Constitution, particularly the rule of law, accountability and responsiveness. We believe that ensuring fairness and equity in the treatment of applicants for building plan approvals, irrespective of where they are in South Africa,

88 Sections 195(1)(e)-(f) of the Constitution. 
would be served by having a broadly coherent and uniform internal appeal regime across municipalities. It is not fair and equitable that there should be an internal appeal mechanism in one municipality and none in the next, or that one municipality should offer a far more efficient internal appeal mechanism than another municipality. Given the advantages of a system of internal appeals pointed out in Part 5 of this article, which advantages outweigh the disadvantages, a municipality that offers an efficient internal appeal mechanism would undoubtedly be a more responsive and accountable municipality. Writing about constitutional supremacy and the rule of law, Michelman posits that all governance (authorised by law) must be aligned with the ideals set out in the Constitution. He asserts that section 1 (c) speaks to the visionary unity of the legal system. Together with other constitutional values, section 1(c) provides for legal harmony for South Africa, where every aspect of law is illuminated by the same vision. ${ }^{89}$

Section 195(3) provides that "[n]ational legislation must ensure the promotion of the values and principles listed in subsection (1)." So how can national legislation promote the said principles in a manner that does not compromise the constitutionally entrenched principle of the autonomy of local government? In our view the answer lies in section 155(7) of the Constitution:

\begin{abstract}
The national government, subject to section 44 , and the provincial governments have the legislative and executive authority to see to the effective performance by municipalities of their functions in respect of matters listed in Schedules 4 and 5, by regulating the exercise by municipalities of their executive authority referred to in section 156(1).
\end{abstract}

Read with section 195(3), section 155(7) in our view impels Parliament to put in place measures that ensure the coherence and uniformity of internal appeal mechanism across municipalities. However, such measures must respect local government's constitutional autonomy. The Constitutional Court in Habitat Councipo has held that section 155(7) empowers the national sphere of government to create "norms and guidelines" for application by municipalities in the exercise of their power. These norms and guidelines must be aimed at achieving a government espousing the values of fairness, equity, responsiveness, accountability and the visionary unity of the legal system.

In our view a good starting point is the internal appeal mechanism contemplated in section 51 of SPLUMA. SPLUMA is the overarching

$89 \quad$ Michaelman "Rule of Law" 37-38.

90 Minister of Local Government v The Habitat Council para 22. 
legislation that guides land use management and development in the country. It defines land development as "the erection of buildings or structures on land, or the change of use of land, including township establishment, the subdivision or consolidation of land or any other deviation from the land use or uses permitted in terms of an applicable land use scheme". As indicated above, the regulation and approval of building plans is a component of general planning law. Looking at the definition of land development, one might think that it is broad enough to cover the approval of building plans. In our view, when the need arose to overhaul the law pertaining to the approval of rezoning and township developments (DFA and the aspects of the land use and township development ordinances), ${ }^{91}$ it would have been opportune to overhaul the law pertaining to the approval of building plans as well. Despite the said broad definition of land development, Parliament elected not to include the NBR Act in the overhaul. There was no repeal of the NBR Act and thus it remained intact. ${ }^{92}$

In our view the success of any internal appeal mechanism depends on who the initial decision maker in a municipality is. Non-definition of who the initialdecision maker is runs the risk that in some municipalities the municipal council can be the initial and inevitably the final decision-maker on a building plan matter. Indeed this is a notable defect in the NBR Act, which states that building plans are approved by a "local authority", which is so broadly defined as to include a full municipal council. As indicated in CoJ Metropolitan Municipality $v$ Chairman of the NBR Review Board, the problem with this is that a municipal council could not sit as an appeal body against its own decisions..$^{93}$ Therefore, in our view, the initial decision-maker must be more specifically defined and should not be the municipal council.

SPLUMA places the power to approve or not approve rezoning and township development applications on a Municipal Planning Tribunal (MPT) staffed by experts and municipal officials, without interference by councillors (politicians). ${ }^{94}$ This approach also allows for collective decision-making by experts and professionals. For the purposes of decisions on building plan, the legislature would have the option of prescribing that each municipality must set up an MPT-type body to make binding decisions on building plans

91 The Transvaal Town-Planning and Townships Ordinance 15 of 1986; the Cape Land Use and Planning Ordinance 15 of 1985; the Natal Town Planning Ordinance 27 of 1949; and the Free State Townships Ordinance 9 of 1969. We perused explanatory memoranda and minutes of committee meetings in the development of SPLUMA, and there was no indication that SPLUMA would regulate building plans as well. Section 36 of SPLUMA. 
(or even that binding decisions be made by the MPT already set up in terms of SPLUMA). Under such a regime building control officers may be retained and will continue to make "recommendations", as is currently the case, with the exception that the recommendation will no longer be made to the "municipality" (which could mean the municipal council) but to an MPT-type body.

Turning to internal appeals, according to section 51(1) of SPLUMA a person whose rights are affected by a decision taken by an MPT may lodge a notice of appeal against that decision (within 21 days) to the municipal manager, who will then submit it to the executive authority of the municipality as the appeal authority. The appeal authority is obliged to consider the appeal and confirm, vary or revoke the decision. This is where we differ from the approach in SPLUMA. In our view the use of municipal executives as the appeal authority for land development applications, including for approval of building plans, may be problematic due to their limited expertise in the area of planning law. As indicated above, one of the core advantages of internal appeals is that they provide a platform that allows for the reconsideration of decisions that are technical, practical, of a policy nature, and often specialised, to be made by experts and people who work on such matters more regularly. We believe that Parliament should empower (even compel) municipalities to establish their own municipal appeal tribunals staffed by appropriately qualified experts who can ensure that norms and standards in the National Building Regulations are applied consistently. This approach is also in line with the option in section 51(6) of SPLUMA, which empowers municipalities to give the appeal power given to executive authorities instead to an external expert appeal body. Section 51(6) of SPLUMA provides that "[a] municipality may, in place of its executive authority, authorise that a body or institution outside of the municipality or in a manner regulated in terms of provincial legislation, assume the obligations of an appeal authority in terms of this section." As indicated above, this approach would allow less-resourced municipalities to still benefit from an expert appeal body without the need to procure their own expert panels.

The approach in SPLUMA is not without cushioning, as the initial decisions made by the MPT would have been made by experts and professionals; and members of the executive authority could always procure the services and advice of experts. Indeed, section 39(1) of SPLUMA empowers the executive authority of a municipality to "co-opt, appoint or employ the services of technical or other advisers" in the performance of their functions. Section 56 also allows executive authorities to delegate their powers to hear internal appeals. It could even be argued that this route could be cost- 
effective and ensure expedited outcomes, as municipalities would not have to appoint external experts to the appeal body and could just rely on the advice of officials in the employ of the municipality. However, in our view, this may still lead to incoherencies and lack of uniformity, as inequality of resources amongst municipalities may lead to decisions in some municipalities being taken without appropriate expertise. The more wellresourced municipalities may be able to appoint advisers on a matter-bymatter basis. The same cannot be said of less-resourced municipalities.

To avert the cost concerns arising from each municipality's having its own appeal body made up of experts (both internal and external), provision could be made in national legislation to give municipalities the powers to establish a shared appeal body on a voluntary basis. This approach would be in line with the duty imposed by the Constitution on national and provincial government to see to the effective performance of municipal functions. As has already been canvassed above and reiterated below, even SPLUMA is not averse to an external body's being an appeal body of a municipality.

It is clear from the discussion of the SPLUMA approach that it provides options for final decisions on appeals to be made not by the executive authority but by experts and professionals either through the delegation of power by the executive authority in terms of section 56 or by the municipality's authorising an external body established in terms of national or provincial legislation to be the appeal body in the place of the executive authority. As laudable as this approach is, the fact that the delegation or outsourcing to experts and professionals would be optional in each instance would likely result in final arbiters in some municipalities being experts and professionals and in others the appellate jurisdiction's remaining with the executive authority (the politicians). In our view, it is within the power of Parliament, in setting out norms and guidelines for municipalities, to insist that final arbitration be performed largely by experts and professionals and not politicians. This would be the best way to advance the ideals of coherence, uniformity, equity and good governance promoted in this article. This does not mean that the executive authority or councillors would be excluded altogether from decision-making. In the first instance, where the municipality sets up its own expert appeal body, councillors would be the ones appointing members of such an appeal body. In the second instance, councillors may still form part of the appeal body. They would just not have the exclusive power to make appeal decisions. Indeed, the limitation of the involvement of politicians is achieved by section 98 of the City of Ekurhuleni Metropolitan Municipality's Spatial Planning and Land Use Management ByLaw, which permits the Municipal Council to set up an appeal authority 
consisting of municipal officials, external experts, officials of other organs of state and municipal councillors (which may include members of the executive authority). However, it is advisable that councillors not be the majority of the personnel in any appeal body, since most of them do not have the requisite technical expertise.

It is important to consider what, if anything, of the erstwhile internal appeal regime under the NBR Act should be retained by the legislature. Of significance about this regime is that appeal decisions were made exclusively by appropriately skilled experts who were selected from amongst and nominated by industry players. The NCRS played a significant role in facilitating the work of the Review Board, including by ensuring that appropriate experts were selected. It would be a pity if the infrastructure of the NCRS were to be lost. We would suggest that in developing an appeal mechanism for decisions under the NBR Act, a role be retained for the NCRS. One of the things that could be done by the NCRS to support the new internal appeal regime could be maintaining a list of qualified and suitable experts from which municipalities would have to select expert members of their appeals committees. It could also serve as an advisory body to municipalities on matters related to internal appeals for decisions about building plans.

\section{Conclusion}

We have sought to provide a comprehensive account of the implications of the decision of the Constitutional Court in CoJ Metropolitan Municipality $v$ Chairman of the NBR Review Board to declare unconstitutional the internal appeal scheme provided in section 9 of the NBR Act on the basis that it violates the constitutionally enshrined principle of the autonomy of local government. In doing so we have taken the opportunity to demonstrate how the erstwhile internal appeal regime under the NBR Act worked, how it fared in comparison with other internal appeal mechanisms designed for municipal decisions, and the general importance of internal appeals for municipalities in the South African context.

We found that the CoJ Metropolitan Municipality $v$ Chairman of the NBR Review Board judgment has left a whopping gap on the topic of where prospective appeals ought to be lodged and the nature thereof, the result being the potential for incoherence and lack of uniformity in building plan decisions, depending on which municipality you are dealing with. Some municipalities would have internal appeal mechanisms while others would have none at all, or one municipality might offer a far efficient internal appeal 
mechanism than another. We found this to be inconsistent with principles and values enshrined in section 195(1) and section 1 of the Constitution, including the rule of law, accountability, responsiveness, impartiality, fairness and equity.

We found that the solution to the said gap lies in a legislative intervention by Parliament. It is within Parliament's power, and indeed within its constitutional duty to provide for a broadly coherent and uniform internal appeal mechanism for decisions about building plans under the NBR Act applicable across municipalities whilst respecting and complying with the constitutional principle of the autonomy of local government. We found that SPLUMA would provide the most appropriate inspiration for a new internal appeal regime for decisions about building plan. At the heart of the necessary reform is the need for decisions, including decisions on appeal, to be made by professionals with expertise at least in the legal, construction and engineering environments. This could be achieved by a legislative enactment that required municipalities to establish expert internal appeal bodies made up of municipal officials, external experts and even municipal councillors - as long as the latter are not in the majority in any appeal body. Such a model has already been adopted by the City of Ekurhuleni Metropolitan Municipality in section 98 of its Spatial Planning and Land Use Management By-Law in respect of municipal planning decisions. To provide for municipalities who may not have the capacity to establish their own expert appeal bodies, national legislation could make provision for them to establish a shared appeal authority.

\section{Bibliography}

\section{Literature}

Fuo 2017 De Jure

Fuo O "Intrusion into the Autonomy of South African Local Government: Advancing the Minority Judgment in the Merafong City Case" 2017 De Jure 324-345

Hoexter 2000 SALJ

Hoexter C "The Future of Judicial Review in South African Administrative Law" 2000 SALJ 484-519

Hoexter Administrative Law

Hoexter C Administrative Law in South Africa $2^{\text {nd }}$ ed (Juta Claremont 2012) 
Govender "Administrative Appeals Tribunals"

Govender K "Administrative Appeals Tribunals" in Bennet TW et al (eds) Administrative Law Reform (Juta Cape Town 1993) 76-87

Michaelman "Rule of Law"

Michaelman F "Rule of Law. Legality and the Supremacy of the Constitution" in Woolman S et al Constitutional Law of South Africa $2^{\text {nd }}$ ed (Juta Cape Town 2015) Vol 1, Ch 11

Quinot et al Administrative Justice

Quinot G et al Administrative Justice in South Africa - An Introduction (Oxford University Press Cape Town 2015)

SALC Project 24

South African Law Commission Project 24: Report - Investigation into the Courts' Powers of Review of Administrative Acts (The Commission Pretoria 1992)

\section{Case law}

City of Johannesburg Metropolitan Municipality $v$ Chairman of the National Building Regulations Review Board 20185 SA 1 (CC)

City of Johannesburg Metropolitan Municipality v Gauteng Development Tribunal 20084 SA 572 (W)

City of Johannesburg Metropolitan Municipality v Gauteng Development Tribunal 20102 SA 554 (SCA)

City of Johannesburg Metropolitan Municipality v Gauteng Development Tribunal 20106 SA 182 (CC)

Georgiou v Nelson Mandela Bay Metropolitan Municipality 20164 All SA 524 (ECP)

JDJ Properties CC v Umngeni Local Municipality 20132 SA 395 (SCA)

Koyabe v Minister for Home Affairs 20104 SA 327 (CC)

MEC for Health, Eastern Cape $v$ Kirland Investments (Pty) Ltd 20143 SA 481 (CC) 
Minister of Local Government, Environmental Affairs and Development Planning of the Western Cape v Lagoonbay Lifestyle Estate (Pty) Ltd 2014 1 SA 521 (CC)

Minister of Local Government, Environmental Affairs and Development Planning, Western Cape $v$ The Habitat Council; Minister of Local Government, Environmental Affairs and Development Planning, Western Cape v City of Cape Town 20144 SA 437 (CC)

Municipality of the City of Cape Town v Reader 20091 SA 555 (SCA)

Oudekraal Estates (Pty) Ltd v City of Cape Town 20046 SA 222 (SCA)

Tronox KZN Sands (Pty) Ltd $v$ KwaZulu-Natal Planning and Development Appeal Tribunal 20163 SA 160 (CC)

Walele v City of Cape Town 20086 SA 129 (CC)

\section{Legislation}

Cape Land Use and Planning Ordinance 15 of 1985

Constitution of the Republic of South Africa, 1996

Development Facilitation Act 67 of 1995

Free State Townships Ordinance 9 of 1969

Local Government: Municipal Structures Act 117 of 1998

Local Government: Municipal Systems Act 32 of 2000

Natal Town Planning Ordinance 27 of 1949

National Building Regulations and Building Standards Act 103 of 1977

National Regulator for Compulsory Specifications Act 5 of 2008

Promotion of Administrative Justice Act 3 of 2000

Spatial Planning and Land Use Management Act 16 of 2013

Transvaal Town-Planning and Townships Ordinance 15 of 1986 


\section{Government publications}

GN 2074 in GG 9927 of 13 September 1985 (Review Board Regulations)

GN R2378 in GG 12780 of 12 October 1990 (National Building Regulations)

GN R239 in GG 38594 of 23 March 2015 (SPLUMA Regulations)

\section{Internet sources}

City of Johannesburg Date Unknown http://www.joburgtourism.com/ files/useruploads/user_anon/files/apps_cellmast.pdf

City of Johannesburg Date Unknown City of Johannesburg Cellular Mast Policy http://www.joburgtourism.com/files/useruploads/user_anon/files/ apps_cellmast.pdf accessed 15 July 2018

NRCS 2019 https://www.nrcs.org.za/content_main.asp?menulD=12 National Regulator for Compulsory Specifications 2019 National Building Regulations https://www.nrcs.org.za/content_main.asp?menulD=12 accessed 5 February 2020

NRCS 2019 https://www.nrcs.org.za/content.asp?subID=4151\#1 National Regulator for Compulsory Specifications 2019 National Building Regulations - Review Board Decisions https://www.nrcs.org.za/ content.asp?sublD=4151\#1 accessed 5 February 2020

\section{List of Abbreviations}

$\begin{array}{ll}\text { DFA } & \text { Development Facilitation Act } \\ \text { MMCs } & \text { Members of the Mayoral Committee } \\ \text { MPT } & \text { Municipal Planning Tribunal } \\ \text { NBR Act } & \text { National Building Regulations and Building } \\ & \text { Standards Act } \\ \text { NRCS } & \text { National Regulator for Compulsory } \\ & \text { Specifications } \\ \text { PAJA } & \text { Promotion of Administrative Justice Act } \\ \text { SALC } & \text { South African Law Commission } \\ \text { SALJ } & \text { South African Law Journal } \\ \text { SPLUMA } & \text { Spatial Planning and Land Use Management } \\ & \text { Act }\end{array}$

